\title{
Composition of Pliocene to Quaternary Mixed Terrigenous and Calcareous Sandy Beds in Contourite Drift Deposits at ODP Site 1119 off New Zealand: Insights Into Sandy Drift Development and Drift Petroleum Reservoir Characterization
}

\author{
Kathleen M. Marsaglia ${ }^{12}$ and Jasmyn M. Nolasco ${ }^{1}$ \\ ${ }^{1}$ Department of Geological Sciences, California State University, Northridge, 18111 Nordhoff \\ St., Northridge, CA 91330-8266 \\ 2Corresponding author: Kathie.marsaglia@csun.edu, 1-818-677-6309
}

\begin{abstract}
ODP (Ocean Drilling Program) Site 1119 was drilled in drift successions deposited by northward flowing currents on the Canterbury slope, South Island, New Zealand. Pliocene ( 3.9 Ma) to Pleistocene drift accumulation was concomitant with tectonic uplift and sediment supply from the Alpine Fault plate boundary to the west, glacial development and eustatic sealevel change that created cyclicity in sandy input. Sand detrital and biogenic modes of very fine and fine sand fractions from 24 unconsolidated core samples (44 thin sections) were determined. Fine sand fractions contain an average of $52 \%$ bioclastic debris, with bioclasts making up $23 \%$ of the very fine sand fraction. Foraminifers are the dominant bioclasts, with pelagic more common than benthic varieties. The average proportions of monocrstalline quartz, plagioclase and potassium feldspar are similar in both size fractions (average QmKP of 25:12:63). In contrast, the very fine sand fractions have, on average, higher lithic (QFL\%L of 16 vs. 3\%), mica (Totalgrain\%M of 10 vs. 6\%), and dense mineral (Totalgrain\%D of 8 vs. 5\%) content as compared with the fine sand fractions. Younger clinoform drape (Unit I) and older mounded drift (Unit II) seismic facies showed no distinct detrital compositional differences in their sand fractions, though bioclast content ranges higher in the fine sand fraction of Unit II. Albite feldspar, metamorphic rock fragment, and chlorite components in the sand are consistent with a schist provenance. Other components such as biotite, plagioclase, and K-feldspar require a contribution from
\end{abstract}


metasedimentary and volcanic rocks. Thus there is some along-slope mixing during sediment transport by south-to-north flowing currents. Cemented microporous sandstone at the base of the section provides some insight into contourite burial diagenesis. This work provides a better understanding of the compositional variability of sand components of drift successions which are potential hydrocarbon reservoirs elsewhere.

Key Words: contourite, sand, sediment drift, Pliocene, Pleistocene, New Zealand, provenance, foraminifers

\subsection{INTRODUCTION}

Contourite drift deposits resulting from ocean bottom currents occur along continental slopes and rises are found in all major ocean basins (e.g., Brackenridge, et al., 2011; HernándezMolina et al., 2011; Rebesco et al., 2014). Along or sub-parallel to slope currents shape the seafloor through oceanographic processes that, in conjunction with sea-floor bathymetry, sediment supply, and turbidity, control drift deposition (e.g., Faugères et al., 1993; Viana et al., 1998; Hernández-Molina et al., 2011; Rebesco and Camerlenghi, 2008; Rebesco et al., 2014). Bottom-current velocities capable of forming contourites can transport up to coarse sand (Shanmugam, 2008). However, most continental-margin contourite drifts comprise dominantly muddy facies with varying proportions of terrigenous and calcareous components (Stow and Holbrook, 1984; He et al., 2008; Stow et al., 2008; Rebesco et al., 2014). The higher terrigenous sand content of some drifts is often a function of sediment supply via glacial processes or results from cannibalization of sediment previously deposited within slope canyons (He et al., 2008; Stow et al., 2008; Rebesco et al., 2014). In contrast, sand-sized biogenic debris (foraminifers) can be supplied directly by settling from the water column (Stow et al., 2008). 
The few comprehensive descriptions of sandy drifts have focused more on their lithofacies and less on their petrology and provenance, as most are composed mainly of foraminifers (e.g., Shanmugam et al., 1993; Viana et al., 1998; Rebesco et al. 2014). Some notable exceptions include terrigenous-dominated drift deposits resulting from Mediterranean outflow in the Gulf of Cadiz (Nelson et al., 1993) recently drilled during Expedition 339 (Stow et al., 2013; Rebesco et al., 2014), the glacially fed sandy contourites (70-80\% sand) at the base of the West Shetland slope (Masson et al., 2010), and the Canterbury drifts recovered at Ocean Drilling Program (ODP) Site 1119 on Leg 181 off New Zealand (Fig. 1; Carter et al., 1999). We focus herein on sandy contourite intervals at Site 1119, reporting on their compositional variability and provenance. Our data constrain terrigenous sand transport distance and source area, characterize the proportion and types of sand-sized biogenic components, and define a temporal trend in foraminifer/bioclast content associated with drift evolution, all of which are factors relevant to evaluating the prospectivity of such deposits as hydrocarbon reservoirs. Drift deposits have been touted as potential hydrocarbon reservoirs, especially where clean, wellsorted sandy contourite facies are overlain and sealed by hemipelagic muddy facies in stratigraphic traps (e.g., Viana et al., 2007; Shanmugam, 2008; Viana, 2008; Stow et al., 2011; Rebesco et al., 2014). Whereas sediment sorting and grain size have been discussed in the literature cited above, sediment composition and its possible link to reservoir character have only been cursorily evaluated and is the focus of this study based on samples from Ocean Drilling Program (ODP) Site 1119.

\subsection{BACKGROUND ON CANTERBURY BASIN AND ODP SITE 1119}

The Canterbury Basin extends offshore from the Canterbury Plains, on South Island, New Zealand (Fig. 1). This is a passive margin setting where Cretaceous rifting was followed by 
thermal subsidence, culminating in Oligocene peak flooding, after which terrigenous shelf progradation was caused by increased sediment delivery and accumulation associated with the development of the nearby Alpine Fault transform plate boundary and associated Southern Alps mountain range (Fulthorpe and Carter, 1991; Browne and Naish, 2003). The outer shelf and slope of the basin run parallel with the northward trend of the modern Southland and Subantarctic Fronts, which have produced significant contourite drift deposits through time. The Canterbury drifts and the modern equivalents of the currents thought to have produced them have been studied and characterized, as summarized by Carter (2007) and Land et al. (2010) and references cited therein. The oldest drift deposits are of earliest Miocene age and are now uplifted and partly exposed onland thanks to Neogene tectonism (Carter, 1988, 2007). Detailed outcrop and seismic stratigraphic studies have defined the geometry and extent of several drifts across the Canterbury foothills, extending under the shelf and slope including the most recent phase (3.9-0 Ma) drilled at ODP Site 1119 (Fig. 2; Carter et al., 1999, 2004a; Fulthorpe and Carter, 1991; Lu and Fulthorpe, 2004).

Site 1119 was drilled in $395 \mathrm{~m}$ water depth and $96 \mathrm{~km}$ east of the present shoreline, and penetrated $\sim 495$ meters of middle to upper slope section with 90\% core recovery (Fig. 3; Carter et al., 1999; 2004b; Carter, 2005). Shipboard scientists described the largely muddy lithologies with mostly unconsolidated sandy interbeds and laminae ( $10 \%$ net sand) along with their sedimentary structures, mainly $\mathrm{cm}$-scale lamination/bedding with sand beds 2-300 $\mathrm{cm}$ thick exhibiting gradational to abrupt tops and bottoms. Only two thin beds in the section were interpreted as turbidites, the remainder as bottom-current deposits. They determined the age of the sediments using bio- and magnetostratigraphic datums and related the section to previously defined seismic stratigraphic units, dividing the succession into three main units (Figs. 2 and 3; 
Carter et al., 1999). They interpreted the lowermost mudstone Unit III to be drape deposits on an underlying sediment drift (Big Grey in Fig. 2) that was not penetrated at this site, but crops out onshore. Overlying sand-bearing muddy deposits of Unit II were subdivided into three subunits corresponding to three seismically defined drifts that represent intermediate-water depth slope deposits. The topmost Unit I was deemed to be a drift drape over upper slope clinoform sediment that exhibits clear glacial-interglacial cyclicity and encompasses sand beds attributed to sediment reworking by temperate water incursions during interglacial highstands, as indicated by the presence of deeper water benthic foraminifers. Terrigenous sediment input was linked to the Southern Alps, with sand described as containing quartz, feldspar and mica. Subsequent work by Carter and others (Carter et al., 2004ab; Carter 2005, 2007; Land et al., 2010) has better defined the age (Fig. 3), sedimentary structures, cyclicity (tuning), grain size, and clay mineralogy of the units. Thus under glacial-river influence and eustatic sea level changes, the development of Canterbury slope accretion has resulted in muddy facies with sandy interbeds that potentially reflect climatic changes (Carter et al., 1999; Carter, 2007). The purpose of our study was to describe and interpret the sand compositional modes of both detrital and biogenic components.

\subsection{METHODS}

Twenty-four sandy intervals from Units I and II at Site 1119 were sampled and sieved to separate the mud from the very fine, fine, and medium sand fractions. A few samples contain sparse grains of coarse sand and/or gravel-sized shell fragments. Grain mounts of the separates were made into petrographic thin sections. The thin sections were then etched with hydrofluoric acid and stained, first, for potassium feldspar using sodium cobaltinitrate, and, second, for plagioclase feldspar identification using barium chloride and amaranth following the method outlined in Marsaglia and Tazaki (1991). After staining, K- feldspar grains are yellow, Ca- 
feldspar grains are pink, and Na-feldspar grains are etched but not stained (Fig. 4). All thin sections were petrographically reviewed. An automated stage on a petrographic microscope and Swift point-counting apparatus were used to determine sand grain types at 400 points for each of the 44 thin sections counted. All fine and very fine fractions, and one medium fraction were counted. The Gazzi-Dickinson method was used in point counting as it minimizes compositional variation owing to grain size of the terrigenous components (Ingersoll, et al., 1984). Sand-sized polymineralic and monomineralic terrigenous components (Fig. 4) were classified using the categories of Shapiro et al. (2007) modified to include the lithic scheme of Garzanti and Vezzoli (2003). Bioclast categories were created based on their phylum/class/order (Table 1), and the more common and diverse foraminifers were subdivided according to their taxonomy, morphology, and ultrastructure as seen in thin section. Various parameters were recalculated (Table 1) to determine trends in the data.

In addition to the sieved unconsolidated to loosely consolidated samples mentioned above, well lithified fragments of sandstone recovered in Core 43X were impregnated with blue epoxy prior to thin section production to highlight porosity and sorting relationships. These thin sections were also examined to describe likely burial diagenetic effects in the succession.

\subsection{RESULTS}

The compositions of the sand samples range from terrigenous-dominated to biogenicdominated. The relative proportions of terrigenous and biogenic components are displayed by grain size in Figure 5. The very fine sand fraction is more terrigenous than the fine sand from

the same sample, with the latter containing more foraminifers (Fig. 5; Table 2). The very fine sand in Unit I is fairly uniform in composition but the percentages of terrigenous debris and 
foraminifers vary down section in Unit II (Fig. 6). The ranges of values for each of the subunits in Unit II are similar with one exception, a sample with 99\% terrigenous components at 288 mbsf, just above the Unit IIA/IIB boundary at the Pliocene/Pleistocene transition in Figure 6 .

The terrigenous sand components are dominated by quartz and feldspar, with higher QFL lithic (QFL\%L) percentages in the very fine sand fraction (Fig. 7) and higher quartz (QmKP\%Qm, QFL\%Q) in the fine sand (Figs. 8). The terrigenous components are mainly feldspar (Table 2) with calcium (Ca), greater than potassium (K), greater than sodium (Na) varieties on average. There are roughly equal proportions in the fine fractions $(\mathrm{Na}: \mathrm{K}: \mathrm{Ca}=$ 29:30:37), and slightly lower $\mathrm{Na}$ and higher $\mathrm{Ca}$ in the very fine fraction ( $\mathrm{Na}: \mathrm{K}: \mathrm{Ca}=21: 35: 44)$. The second most common component is quartz (Fig. 7), both monocrystalline and polycrystalline varieties, including chert and metamorphic types showing elongated and dislocation subgrains (Table 2). The Site 1119 sand shows three distinct populations with average Qm:K:P ratios for the fine sand fractions as follows: 1) 36:12:52; 2) 25:13:62; and 3) 16:14:70. These manifest as clusters of data points labeled Types 1, 2, and 3 respectively on the QmKP ternary plot in Figure 8. The fine-sand fractions show a similar range of values (Fig. 8), but there is less clustering.

On average, the very fine sand is more enriched in lithic fragments (Fig. 7). The lithic types are mainly higher-grade metamorphic lithic clasts such as quartz-mica tectonite, with some biotite and chlorite-bearing varieties (Table 2). Low-grade metasedimentary fragments (LmfLmp) are present in significant amounts in a few samples. Rare sedimentary lithics are mudstone varieties that could be intraclasts, and pellets or gloms (aggregates) of matrix created during sample processing of semi-lithified muddy sediment. The average total grain percentages of mica, including muscovite (M), biotite (B) and chlorite (Ch), decreases from $10 \%$ to $6 \%$ in the very fine-to-fine fractions, respectively, along with the average percentages of dense minerals, 
from $9 \%$ to $5 \%$. The proportions of micas in the very fine sand are, on average, $\mathrm{M}: \mathrm{B}: \mathrm{Ch}=$ 38:22:40, as opposed to the fine sand where they are M:B: $\mathrm{Ch}=16: 26: 58$. The dense minerals include zoisite, clinozoisite and opaque minerals that were counted separately and a variety of others, dominated by green amphibole. Traces of glauconite and coarse carbonate are present in some samples, the latter authigenic or biogenic in origin. Notably, there are no significant downhole trends in recalculated detrital modes of the above terrigenous components (see Table 2).

The biogenic components are mainly foraminifers (Fig. 4; Table 2), whole to fragmented, with planktonic varieties dominating over benthic types, consistent with observations of 60-95\% planktonic taxa, in particular globigerinids, by shipboard paleontologists (Carter et al., 1999). Although foraminifers are usually identified using whole (3-D) specimens in loose sediment, we tried to evaluate differences in populations based on their attributes in 2-D, thin section views. Several groups could be discriminated in thin section based on form and ultrastructure (e.g., globigerinid, agglutinated, biserial, miliolid, and evolute varieties; Table 2). Ternary plots were constructed to show this variability (Fig. 9), with very fine sand fractions being enriched in miliolid with respect to globigerinid, and evolute types with respect to agglutinated types. There were no discernable downhole trends except for the lower overall bioclast and foraminifer content in Unit I (Fig. 6). Other recognizable bioclast types present in trace amounts include fragmented to whole mollusks, echinoderms, siliceous and calcareous sponge spicules, tunicate spicules, ostracodes, red algae, brachiopods, and corals. Some bioclasts show microborings and/or infilling by glauconite.

Petrographic review of thin sections of medium sand fractions shows them to be dominated by bioclasts, mainly foraminifers, with some echinoid spines and plate fragments. Other bioclasts include fragments of mollusks, ostracodes, barnacles, sponge spicules and 
brachiopods. The siliciclastic fraction contains similar components to the fine and very fine sand described above. Only one medium grained sand fraction (topmost sample in core $1 \mathrm{H}$ ) with subequal amounts of terrigenous and bioclastic debris was point counted for comparison with the fine and very fine fractions (for rationale behind this decision see below). In the coarser fractions, there is progressively more mica and plagioclase and less lithic fragments.

The well lithified fragments of sandstone in Core 43X were impregnated with blue epoxy to make diagenetic observations relevant to the ultimate reservoir characteristics of such deposits. These are summarized in photomicrographs and captions in Figure 4. There are major, mm-scale changes in microporosity as a function of bioturbation and sorting, with some larger oversized pores possibly reflecting dissolution of aragonitic bioclasts. There is also submicroscopic porosity owing to partial dissolution of bioclasts, including mollusks and miliolid foraminifers, as seen where the blue-epoxy impregnation imparts a bluish tinge to the fragments in thin section (Fig. 4).

\subsection{DISCUSSION}

\subsection{Sand Composition and Provenance}

Contourites around the globe exhibit compositions ranging from carbonate end members dominated by pelagic bioclasts to terrigenous-dominated where the drifts are built from glaciomarine debris. The overall composition of Canterbury drift sand (Table 2) corresponds with data from the literature, for example drifts from the North Atlantic Ocean contain a maximum of $\sim 80 \%$ terrigenous components (He et al., 2008; Holbrook et al, 1984).

The sand content of contourite drifts is a function of the presence of a sand-rich source area in the path of the currents (Rebesco et al., 2014). In the case of the Site 1119 deposits, 
terrigenous debris could have been supplied via northeast-flowing shelf to slope currents during highstands, or by passage of slope currents across submarine canyons (sand conduits) to the south or from the northwest by shelf edge delta deposits during lowstands. Bioclasts could have been similarly sourced along the path of the current or added in situ via settling through the water column or by accumulation of local benthic community debris.

Carter (2007) performed grain-size analyses on these cores and showed trends for these drift deposits in terms of their sand, sortable silt, and cohesive mud content, comparing them to onshore outcrops of similar, but slightly older drift deposits. On average he found the Site 1119 sand beds to contain approximately $62 \%$ sand, $23 \%$ sortable silt, and $15 \%$ cohesive mud. These percentages are roughly what McCave (2008) showed for flow speeds of $25 \mathrm{~cm} / \mathrm{s}$, commenting that at $30 \mathrm{~cm} / \mathrm{s}$ there would be less mud. For comparison, transport of medium quartz sand would require currents of $35-37 \mathrm{~cm} / \mathrm{s}$ (McCave, 2008).

Stow and Faugères (2008) suggest that terrigenous/biogenic ratios and benthic/planktic ratios, and presence/absence of far-travelled components might help define local vs. regional effects in drift deposits. Compositional variability can also be a product of sorting during transport, as according to McCave (2008) the "transport and deposition of contourites [involves] many cycles of erosion and deposition under intermittently strong deep-sea currents, [producing] fine sediments that show some sorting." Stow et al. (2008) suggest that bed-load, saltation and suspension-transported fractions may show different compositions owing to hydrodynamic sorting during transport and deposition.

To test this hypothesis, we point-counted different size fractions, focusing on very fine and fine sand, as these grain sizes were present in every sample in sufficient quantities that 
allowed for counting up to 400 grains, resulting in more robust statistical basis for comparing compositions of different samples. Despite the use of the Gazzi-Dickinson method to minimize compositional differences owing to grain size, there are some significant differences in fine and very fine terrigenous sand fractions as shown by the differences in average values for fine and very fine fractions in Table 2 and data distributions in Figures 5, 7 and 9. These could reflect natural variation in a single source or modification by hydraulic sorting or potentially mixing of several sources as discussed below.

Shipboard scientists divided the succession at ODP Site 1119 into three mud-dominated units (Fig. 3), the upper two (I and II) sand bearing, and the older one (III) with no discrete sand beds. Our samples were taken from the top two sand-bearing units, which correlate to distinct seismic facies: Unit II, drift deposits, and Unit I, interpreted as drape deposits (Fig. 2). Analysis of the petrographic data collected in this study shows significant changes in the proportions of terrigenous and foraminifer components between the two units/seismic facies (Fig. 6). Unit I has fairly uniform terrigenous ( $\sim 0 \%)$ and foraminifer ( 18\%) content. These components are , more variable in Unit II sand, which exhibits higher foraminifer content.

A review of the literature suggests several options for the beds with higher foraminifer/bioclast content in Unit II (Fig. 6). First, the planktonic foraminifers may have been a product of higher local productivity or perhaps, higher productivity "upstream” along the current trace. McCave (2008) suggests that lateral flux in contourite deposits is mainly in the mud fraction with sand flux a function of vertical addition of pelagic debris, as the current velocities needed to transport foraminiferal sand are generally not enough to produce well-sorted sand. Thus in many instances foraminiferal sand is a product of winnowing by weak currents. However, in the case of the Canterbury drifts, we know that the lateral flux has included 
terrigenous sand-sized material based on sand composition as described below, so there was likely bioclast transport as well. Transport of very fine to fine sand-sized foraminifers by contour currents on the Canterbury Margin should have been commonplace, as McCave (2008) states that medium sand sized foraminifers have the erodibility of very coarse silt and the settling velocity of very fine sand, and Stow et al. (2008) indicates up to fine sand can be transported as suspended load by contour currents.

The relatively constant foraminifer percentage in Unit 1 (Fig. 6), interpreted as drape deposits, suggests that this may be the background level of pelagic addition from the water column, with the bioclast-rich excursions in Unit II more likely related to changes in margin water productivity or bottom current strength. The Unit I drape deposits might be a response to lowstand conditions, which would imply slowing of bottom current strength and contourite accumulations and condensed drift development. They could also just be a product of build-out of shelf deposits which affected accommodation space as discussed by Brakenridge et al. (2011). The higher biogenic concentrations could also result from decreases in terrigenous sediment influx (change in source or amount?) and increased bottom water current strength as discussed by Brakenridge et al. (2011). We did note glauconite fillings and microborings of some bioclasts indicative of bioclast reworking.

Benthic foraminifers (miliolid) are more abundant in the very fine fraction and planktonic (globigerinid) foraminifers are concentrated in the fine fraction at Site 1119 (Fig. 9), possibly related to density differences between them indicating some hydraulic sorting effects within the foraminifer population. In addition, there are differences in the terrigenous component size fractions, with dense minerals and micas concentrated in the very fine fractions (Table 2), also 
attributable to hydraulic sorting effects. However we cannot rule out the possibility that these size differences are inherited from the source rocks or natural foraminifer population.

Just how far were the terrigenous components transported? Our assumption was that the terrigenous components were not supplied by river systems directly west of the Site 1119, like the modern Rangitata River (fig. 1), but were transported by the northeast flowing currents that skirt the eastern margin of South Island, New Zealand. Today, a series of submarine channels link the shelf (and rivers during lowstands) to the deeper water submarine fan system in the Bounty Trough (Fig. 1). As sediment was supplied to the Bounty Fan during the late Pliocene and Pleistocene (Shapiro et a., 2007), there must have been similar submarine slope canyon systems active during the accumulation of the Canterbury drifts encountered at Site 1119. Currents crossing these canyons may have captured sediment from the canyons and canyon walls, carried it along the slope, and ultimately deposited it at Site 1119. Luckily the geology of South Island is varied, so that the composition of sand fed by streams to the shelf and slope may be used as a tracer, linking source to sink. Higher-grade schist in the south (Fig. 1; the Otago or Haast Schist) sheds quartzo-feldspathic micaceous sand whereas clastic sedimentary to metasedimentary units in central South Island (Fig. 1; the Torlesse composite terrane) shed quartzolithic sand with little mica (Shapiro et al., 2007; Bender-Whitaker, 2013). This variability is evident on the QFL plot of Site 1119 data in Figure 7, where fine sand is more similar to sand with schist provenance from the Clutha River while some very fine sand is enriched in lithic fragments and more similar to sand with metasedimentary (Torlesse Group) or semi-schist provenance from the Waitaki and Rangitata rivers. In finer detail, the proportions of mica and metamorphic lithics are more similar to the Waitaki and Clutha rivers as demonstrated by the compositional ranges in Figure 10. 
Given the rather limited compositional variation in the detrital components of samples at Site 1119, the QmKP proportions are another indication of potential provenance changes in the terrigenous fraction. The three distinct very fine sand populations (Types 1, 2, and 3) observed in Figure 8 are mainly defined by their plagioclase/quartz content. There are no corresponding consistent patterns in total\%dense minerals or total \%mica among the three groups, so these clusters in QmKP\%Qm are not likely a product of hydraulic sorting. Instead they may be linked to sediment provenance. Modern onshore river sources (proxies) show the highest QmKP\%P (42\%) and lowest QmKP\%Qm (57\%) in very fine sand from the Clutha River, which drains mainly schist lithologies. Furthermore very fine sand from the Clutha River has a QFL (55:39:6) that is also similar to that of Type 1 sand from Site 1119 (50:43:7), as well as similar mica to metamorphic lithic proportions (Fig. 10), making the schist provenance river the best fit with regard to source, particularly of Type 1 sand. The average QmKP of the Type 1 and Type 3 beds is approximately the mean value of the Type 2 beds (26:13:61), suggesting that the Type 2 beds are mixtures of Type 1 and Type 3 components but there is not a continuum of compositions to support a mixing hypothesis. The provenance of Type 3 beds is somewhat problematic, in that they have high plagioclase content. Potential plagioclase sources include mafic volcanic units that crop out along the coastal regions (Fig. 1), yet the Type 3 samples have no volcanic lithics and have similar range of metamorphic and mica components to the other groups.

All three compositional types of beds are present in Unit II whereas only Types 1 and 2 are found in Unit I. In the upper $87 \mathrm{~m}$ (Unit I) there is no relationship between the occurrence of type 1 and 2 beds and the patterns of water mass interaction determined by Carter et al. (2004b) based on the carbonate isotope record from the site; however, our sample spacing was at a much lower resolution as compared to Carter et al. (2004b). Carter et al. (2004b) discuss the interval 
that includes our topmost (youngest) sand sample (Type I) as being inconsistent with the current highstand, low energy conditions and propose that at between 9.5-12.9 ka there was a current strengthening event with temperate fauna linking them to subtropical water flow. Note that in support of current strengthening, this sample was the only one with a significant terrigenous component in the medium sand fraction, which was point-counted (Table 2).

In sum, there is evidence for long-distance transport of sand along the South Island slope via cannibalization of slope-canyon sediments with a schist to semi-schist provenance, potentially augmented by input from coastal mafic volcanic sources. This implies that potential distances of along-slope sand transport range up to $200 \mathrm{~km}$ (Fig. 1). This is important, as in other sandy contourite systems around the globe, sediment transport distance may be indeterminate or equivocal.

\subsection{Contourite Reservoir Implications}

We have focused on the sand fractions in unlithified samples, whereas the actual grainsize variation in the contourites would partly determine their reservoir potential by affecting their porosity and permeability. Bulk grain-size data reported by Carter (2007) are also somewhat misleading as reservoir indicators because bioturbating organisms may redistribute the mud and sand fractions in these beds creating zones with more and less microporosity/permeability. In addition, the bioclasts themselves can hold primary intraparticle porosity (foraminifer chambers) or be susceptible to secondary dissolution. Thus a true picture of the reservoir potential of these samples can only be attained when they are sufficiently lithified by compaction and/or cementation to allow for whole-sample thin sectioning. 
Leg 181 shipboard paleontologists reported enhanced induration and micrite formation in muddy lithologies in washed mudstone cuttings starting in Core 28X and significant dissolution and, overgrowth and recrystallization of nannofossils starting in Core 34X, with common glauconite in what they describe as a condensed section (Carter et al., 1999). The first indication of minor micrite cement in sand samples collected for this study is present in the Late Pliocene Unit IIC in Core 39X ( 360 mbsf) with progressively better cemented intervals in Cores $42 \mathrm{X}$ to Core $43 \mathrm{X}$ ( $\sim 400 \mathrm{mbsf})$. Core $43 \mathrm{X}$ contains the deepest sand interval penetrated, in the form of fragments of carbonate cemented sandstone (Figs. 3, 4). This is the depth range where active burial cementation is thought to be occurring in nearby Site U1352 (Fig. 1) based on porewater geochemistry and petrographic observations of incipient cementation and pressure solution of bioclasts in sediments with similar-composition (Marsaglia et al., in review; Carson and Marsaglia, 2015). Thus the sandstone at Site 1119 only illustrates a stage in the burial diagenesis of such rocks in one potential pathway of primary porosity enhancement through secondary dissolution of unstable carbonate bioclasts with associated carbonate cementation. Further burial of this mixed carbonate-terrigenous margin succession, as documented at nearby Site U1352 (Marsaglia et al., in review), would progressively diminishes primary and secondary porosity via pressure solution and carbonate cementation. Based on these observations we suggest that such mixed carbonate-terrigenous contourite deposits may be potential reservoirs only where they have not experienced deep burial, or have experienced early hydrocarbon charging (e.g., Wilkinson and Haszeldine, 2011) prior to deep burial.

\subsection{CONCLUSIONS}

Detrital modes of the terrigenous sand fractions at Site 1119 generally indicate a mixing of onshore sediment sources including debris derived from schist, metasedimentary and volcanic 
rocks that are known to crop out onshore to the south of the site, implying drift transport distances up to hundreds of $\mathrm{km}$. The main differences between fine and very fine sand fractions are that the proportions of foraminifers are higher in the fine fractions, whereas the proportions of lithic fragments, dense minerals and micas are higher in the very fine fractions. Each of these trends may be a linked to transport/depositional sorting processes associated with hydrodynamic equivalency. Notably there are no distinct downhole trends in terrigenous sand detrital modes, implying a fairly uniform source of material over the history of drift (Unit II) accumulation. However, in the drift deposits of Unit II the very fine sand is more variable in composition with respect to percent foraminifers/biogenic debris than the Unit I deposits interpreted as seismic drape. Limited observations of Site 1119 sandstone suggest that the potential of such mixed carbonate-terrigenous sandy contourites to be hydrocarbon reservoirs is negatively affected by their sorting and degree of bioturbation, and proportion of unstable carbonate bioclasts prone to dissolution and pressure solution. Comparison with data from a nearby deep IODP drill Site U1352 (Fig. 1) suggests that Site 1119 countourite drift reservoir potential would likely be diminished by further burial diagenesis.

\section{ACKNOWLEDGMENTS}

This study was made possible through an REU supplement to NSF grant \#OCE-1060703. Thanks to John Jaeger (Fig. 1) and Robert Carter (Fig. 2) for supplying figures modified for use in this paper, and Robert Carter, Greg Browne and an anonymous reviewer for their constructive comments on the manuscript.

\section{REFERENCES CITED}


Bender-Whitaker, C., 2013, Holocene-Pleistocene sand provenance in the Canterbury Basin, eastern South Island, New Zealand, MS Thesis, California State University Northridge, 103 p.

Brackenridge, R., Stowe, D.A.V. and Hernandez-Molina, F.J., 2011, Contourites within a deepwater sequence stratigraphic framework. Geo-Marine Letters, 31, p. 343- 360.

Browne, G.H. and Naish, T.R., 2003, Facies development and sequence architecture of a late Quaternary fluvial-marine transition, Canterbury Plains and shelf, New Zealand: Implications for forced regressive deposits. Sedimentary Geology, v. 158, p. 57-86.

Carson, D. and Marsaglia, K.M., 2015, Data report: preliminary investigation of carbonatecemented zones in IODP cores from Canterbury Basin, South Island, New Zealand. Proceedings of the Ocean Drilling Program, v. 317, doi:10.2204/iodp.proc.317.204.2015

Carter, R.M., 1988, Post-breakup stratigraphy of the Kaikoura Synthem (Cretaceous-Cenozoic), continental margin, southeastern Ne Zealand. New Zealand Journal of Geology and Geophysics, v. 31, p. 405-429.

Carter, R.M., 2005, A New Zealand climatic template back to c. 3.9 Ma: ODP Site 1119, Canterbury Bight, south-west Pacific Ocean, and its relationship to onland successions. Journal of the Royal Society of New Zealand, v. 35, p. 9-42.

Carter, R.M., 2007, The role of intermediate-depth currents in continental shelf-slope accretion: Canterbury drifts, SW Pacific Ocean. in Viana, A.R., and Rebesco, M., eds., Economic and Palaeoceanographic Significance of Contourite Deposits, Geological Society, London Special Publications 276, p. 129-154. 
Carter, R.M., Fulthorpe, C.S. and Lu, H., 2004a, Canterbury Drifts at ocean Drilling Program Site 1119, New Zealand: Climatic modulation of southwest pacific intermediate water flows since 3.9 Ma. Geological Society of America, v. 32, p. 1005-1008.

Carter, R.M., Gammon, P.R., and Millwood, L., 2004b, Glacial-interglacial (MIS 1-10) migrations of the Subtropical Front across ODP Site 1119, Canterbury Bight, Southwest Pacific Ocean. Marine Geology, v. 205, p. 29-58.

Carter, R.M., McCave, I.N., Richter, C., Carter, L., et al., 1999, Site 1119: Drift Accretion on Canterbury Slope. Proceedings of the Ocean Drilling Program, Initial Reports, v. 181, p. 1112.

Coates, G., 2002, The rise and fall of the Southern Alps. Canterbury University Press, Christchurch, $80 \mathrm{p}$.

Faugères, J.C., Mézerais, M.L., and Stow, D.A.V., 1993, Contourite drift types and their distribution in the North and South Atlantic Ocean basins. Sedimentary Geology, v. 82, p. 189-203.

Forsyth, P.J., and Aitken, J.J., 1995, New Zealand Minerals and Rocks, Institute of Geological and Nuclear Sciences Information Series 36, 45 p.

Fulthorpe, C.S. and Carter, R.M., 1991, Continental- Shelf progradation by sediment drift accretion. Geological Society of America Bulletin, v. 103, p. 300-309.

Garzanti, E. and Vezzoli, G., 2003, A Classification of Metamorphic Grains in sands based on their Composition and Grade. Journal of Sedimentary Research, v. 73, p. 830-837. 
He, Y., Duan, T., and Gao, Z., 2008, Sediment entrainment, in Rebesco, M., and Camerlenghi, A., eds., Contourites: Developments in Sedimentology 60, Elsevier, Amsterdam, p. 101-142.

Hernández-Molina, F.J., Stow, D.A.V., Llave, E., Rebesco, M., Ercilla, G., Van Rooij, Mena, A., Vázquez, J.T., Voelker, A.H.L., 2011, Deep-water Circulation: Process \& Products (16-18 June 2010, Baiona): introduction and future challenges. Geo-Marine Letters, v. 31, p. 285300.

Ingersoll, R.V., Bullard, T.F., Ford, R.L., Grimm, J.P., Pickle, J.D., and Sares, S.W., 1984, The effect of grain size on detrital modes: A test of the Gazzi- Dickinson point-counting method. Journal of Sedimentary Petrology, v. 54, p. 103-116.

Land, M., Wust, R.A.J., Robert, C., and Carter, R.M., 2010, Plio-Pleistocene paleoclimate in the Southwest Pacific as reflected in clay mineralogy and particle size at ODP Site 1119, SE New Zealand. Marine Geology, v. 274, p. 165-176.

Lu, H., and Fulthorpe, C.S., 2004, Controls on Sequence stratigraphy of a middle MioceneHolocene, current-swept, passive margin: Offshore Canterbury Basin, New Zealand. GSA Bulletin, v. 116, p. 1345-1366.

Marsaglia, K.M., and Tazaki, K., 1992, Diagenetic trends in Leg 126 sandstones. Proceedings of the Ocean Drilling Program, Scientific Results, v. 126, p.125-138.

Marsaglia, K.M., Browne, G.H., George, S.C., Kemp, D., Jaeger, J., Carson, D., Richaud, M., and IODP Expedition 317 Scientific Party, in review, The transformation of sediment into rock: Insights from IODP Site U1352, Canterbury Basin, New Zealand. Journal of Sedimentary Research. 
Masson, D.G., Plets, R.M.K., Huvenne, V.A.I., Wynn, R.B., and Bett, B.J., 2010, sedimentology and depositional history of Holocene sandy contourites on the lower slope of the FaroeShetland Channel, northwest of the UK. Marine Geology, v. 268, p. 85-96.

McCave, I.N., 2008, Size sorting during transport and deposition of fine sediments: Sortable silt and flow speed. in Rebesco, M., and Camerlenghi, A., eds., Contourites: Developments in Sedimentology 60, Elsevier, Amsterdam, p.121-142.

Nelson, H., Baraza, J., and Maldonado, A., 1993, Mediterranean undercurrent sandy contourites, Gulf of Cadiz, Spain. Sedimentary Geology, v. 82, p. 103-131.

Rebesco, M., and Camerlenghi, A., eds., 2008, Contourites: Developments in Sedimentology 60, Elsevier, Amsterdam, 663p.

Rebesco, M., Hernández-Molina, F.J., Van Rooij, D., and Wåhlin, A., 2014, Contourites and associated sediments controlled by deep-water circulation processes: State-of-the-art and future considerations. Marine Geology, v. 352, p. 111-154.

Shanmugam, G., 2008, Deep-water bottom currents and their deposits, in Contourites, Rebesco, M., and Camerlenghi, A., eds., Elsevier, Amsterdam, p. 59-81.

Shanmugam, G., Spalding, T.D., and Rofheart, D.H., 1993, Process sedimentology and reservoir quality of deep-marine bottom-current reworked sands (sandy contourites); an example from the Gulf of Mexico. AAPG Bulletin, v. 77, p. 1241-1259.

Shapiro, S.A., Marsaglia, K.M., and Carter, L., 2007, The petrology and provenance of sand in the Bounty submarine fan, New Zealand. in Arribas, J., Critelli, S., and Johnsson, M.J., eds., 
Sedimentary Provenance and Petrogenesis: Perspectives and Petrography and Geochemistry: Geological Society of America Special Paper 420, p. 277-296.

Stow, D.A.V., and Faugères, J.-C., 2008, Contourite facies and the facies model, in Rebesco, M., and Camerlenghi, A., eds., Contourites: Developments in Sedimentology 60, Elsevier, Amsterdam, p. 223-250.

Stow, D.A.V. and Holbrook, J.A., 1984, North Atlantic contourites: and overview, in Stow, D.A.V., and Piper, D.J.W., eds., Fine-grained sediments: deep-water processes and facies, Geological Society Special Publication 15, p. 245-256.

Stow, D.A.V., Hunter, S., Wilkinson, D., and Hernández-Molina, F.J., 2008, The nature of contourite deposition, in Rebesco, M., and Camerlenghi, A., eds., Contourites: Developments in Sedimentology 60, Elsevier, Amsterdam, p. 143-156.

Stow, D.A.V., Brackenridge, R., and Hernández-Molina, F.J., 2011, Contourite sheet sands: New deepwater exploration target. AAPG Search and Discovery Article \#30182, 24p.

Stow, D.A.V., Hernández-Molina, F.J., Alvarez Zarikian, C.A., and the Expedition 339 Scientists, 2013, Proceedings of the Integrated Ocean Drilling Program, v. 339, Tokyo (IODPMI), doi10.2204/iodp.proc.339.2013.

Suggate, R.P., 1990, Late Pliocene and Quaternary glaciations of New Zealand. Quaternary Science Review, v. 9, p. 175-197.

Viana, A.R., 2008, Economic relevance of contourites, in Rebesco, M., and Camerlenghi, A., eds., Contourites: Developments in Sedimentology 60, Elsevier, Amsterdam, p.493-510. 
Viana, A.R., Faugères, J.-C., and Stow, S.A.V., 1998, Bottom-current-controlled sand deposits a review of modern to shallow- to deep-water environments. Sedimentary Geology, v. 115 p. 53-80.

Viana, A.R., Almeida, W., Jr., Nunes, M.C.V., and Bulhões, E.M., 2007, The economic and importance of contourites. Geological Society, London, Special Publications, 276, p. 1- 23.

Wilkinson, M., and Haszeldine, R.S., 2011, Oil charge preserves exceptional porosity in deeply buried, overpressured, sandstones: Central North Sea, UK. Journal of the Geological Society, v. 168, p. 1285-1295.

\section{TABLE CAPTIONS}

Table 1. Counted and recalculated parameters

Table 2. Point-count data and recalculated percentages

\section{FIGURE CAPTIONS}

Figure 1. Site location map. Geologic and bathymetric map of South Island, New Zealand with fluvial drainages and main drainage basins, a simplified geology after Forsythe and Aitken (1995) and glacial extent during last glacial maximum from Coates (2002) after Suggate (1990). Ocean Drilling Program Site 1119 is highlighted in yellow, with more recent Integrated Ocean Drilling Program (Expedition 317) sites U1351-U1354 also shown. Southwest to northeast flowing shelf currents are indicated, as well as the large scale 
Southland Front. Short line passing through Site 1119 is location of seismic line pictured in

Figure 2. Red star highlights location of Clutha River sediment input to the shelf sedimentary system. Blue star highlights area where Waitaki and Rangitata rivers transmit sediment to the shelf. Similar star symbols are used to denote the composition of sediment from these rivers on Figure 7.

Figure 2. Northwest-southeast oriented seismic section showing the location of and units drilled at Site 1119, as well as local hydrodynamic conditions. The present boundary between water masses is also shown: ASW (Australasian surface water) and SAMW (Subantarctic mode water). Big Grey refers to drift D11 of Lu and Fulthorpe (2004), which was not penetrated at Site 1119. The seismic line is located in Figure 1. Figure modified from Carter et al. (2004a).

Figure 3. Stratigraphic columns with sandy intervals (yellow) for the upper part (Units 1 and 2) of Site 1119 after Carter et al. (1999). Sample intervals for this study are indicated. Age estimates in Ma (red) are from Land et al. (2010).

Figure 4. Petrographic images of selected loose grain types and textures in cemented intervals. A) Loose grains in unconsolidated sample illustrating how staining technique is used in plane-polarized light to differentiate pink-stained calcium feldspar (p) from yellow-stained potassium feldspar (k) from unstained and unetched quartz (q). Also shown is a metamorphic lithic fragment (Lmt: quartz-mica tectonite). Sample 22x-7-13. B) Same view as in A but with polars crossed. C) A cluster of sedimentary to metamorphic lithic fragments in sample 31X-4-55 under plane-polarized light. D) General field of view of poorly sorted, matrix rich, contourite showing the mix of terrigenous (largely white) and bioclast (largely tan) debris. The sample has been impregnated with blue-dyed epoxy to highlight porosity. 
Highlighted is miliolid foraminifer (mi) where the chamber pores are partly filled by microcrystalline carbonate cement, in contrast to adjacent globigerinid foraminifers whose chambers are completely infilled by carbonate cement (cf). The test of the miliolid has a slight bluish tint where secondary dissolution (submicroscopic porosity) has occurred. Other semi-rectangular bioclasts show a similar texture. Glauconite grain is to the left of the "g". Sample 42x-1-2. E) General field of view of burrowed, poorly sorted contourite under planepolarized light. The sample has been impregnated with blue-dyed epoxy to highlight pore spaces, which are unevenly distributed and variable in size. The largest pore (c), may be a secondary pore after dissolution of a bioclasts, or result from bioturbative segregation of coarser fragments. It is partly filled by small carbonate crystals. The dark oval feature in the upper left (b) is a zoned burrow fill, where the matrix outer rim and sand-filled center are both microporous. Biogenic debris includes echinoid spine (e) and mollusk (mo) fragments, as well as opaline sponge spicules (white hollow cross-sections), locally clustered (s). Elongate mica (right of $\mathrm{m}$ ) and rectangular feldspar (left of m). Sample 42x-4-3. F) Same view as in E but with polars crossed. Note bright linear birefringence of echinoid spine and grey to white birefringence of feldspar and quartz, bright blue birefringence of mica, and isotropic (black) nature of opaline sponge spicules.

Figure 5. Ternary of Terrigenous, Foraminifer and Other Bioclast percentages in Site 1119 very fine and fine sand fractions. See Table 1 for formulae for recalculated parameters and Table 2 for data.

Figure 6. Dowhnole plot of percent terrigenous debris (as opposed to biogenic components) and percent foraminifers in Site 1119 very fine sand fractions. See Table 1 for formulae for recalculated parameters and Table 2 for data. 
Figure 7. Ternary plot that displays the proportions of total quartz (Q), feldspar (F) and lithic fragments (L) in Site 1119 samples plotted by grain size. Note that the two grain-size fractions display similar ranges of quartz and feldspar content but the very fine sand is locally enriched in lithic components. The stars show values for local rivers from Shapiro et al. (2007). The Rangitata River drains mainly Torlesse rocks, the Clutha River drains mainly Otago schist rocks, whereas the Waitaki River drains a mixture of the two as shown in Figure 1. The pattern suggests some potential mixing of sediment along strike as discussed in the text. See Table 1 for formulae for recalculated parameters and Table 2 for data.

Figure 8. Ternary plot that displays the proportions of monocrystalline quartz (Qm), plagioclase (P) and potassium feldspar (K) in Site 1119 samples plotted by grain size. Note that the two grain-size fractions display similar range of data values and nearly identical means but there is slight clustering of data into three types the implications of which are discussed in the text. See Table 1 for formulae for recalculated parameters and Table 2 for data.

Figure 9. Ternary plots displaying the relative proportions of various foraminifers in fine and very fine size fractions that could be discriminated petrographically based on morphology and ultrastructure. Examples of each are displayed as follows: A) Globigerinid, B) miliolid, C) biserial, D) evolute, and E) agglutinated. The very fine sand is relatively enriched in miliolid and evolute forms, whereas the fine sand contains more agglutinated and Globigerinid varieties. See Table 1 for formulae for recalculated parameters and Table 2 for data 
Figure 10. Ternary plot that displays the proportions of metamorphic lithic components, low grade (LG) and high grade (HG), as well as mica (M) in Site 1119 samples plotted by grain size. River names are placed in the general area where their compositional modes occur based on data from Shapiro et al. (2007) and Bender-Whitaker (2013). The Rangitata River drains mainly Torlesse rocks, the Clutha River drains mainly Otago schist rocks, whereas the Waitaki River drains a mixture of the two as shown in Figure 1. See Table 1 for formulae for recalculated parameters and Table 2 for data. This plot was devised by Bender-Whitaker (2013) to help discriminate regional sand provenance at nearby Expedition 317 sites (Fig. 1). 
Figure 1

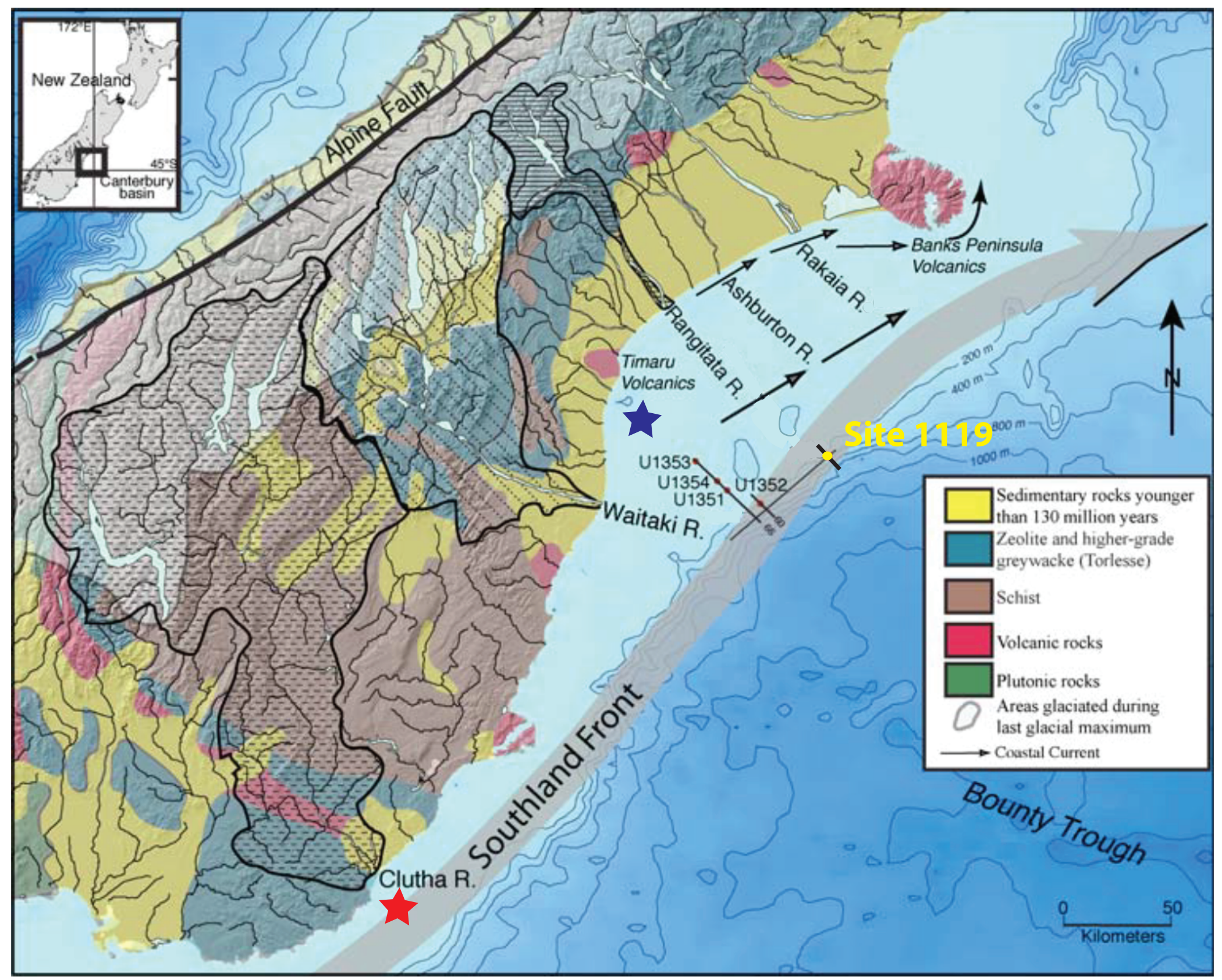


Figure 2

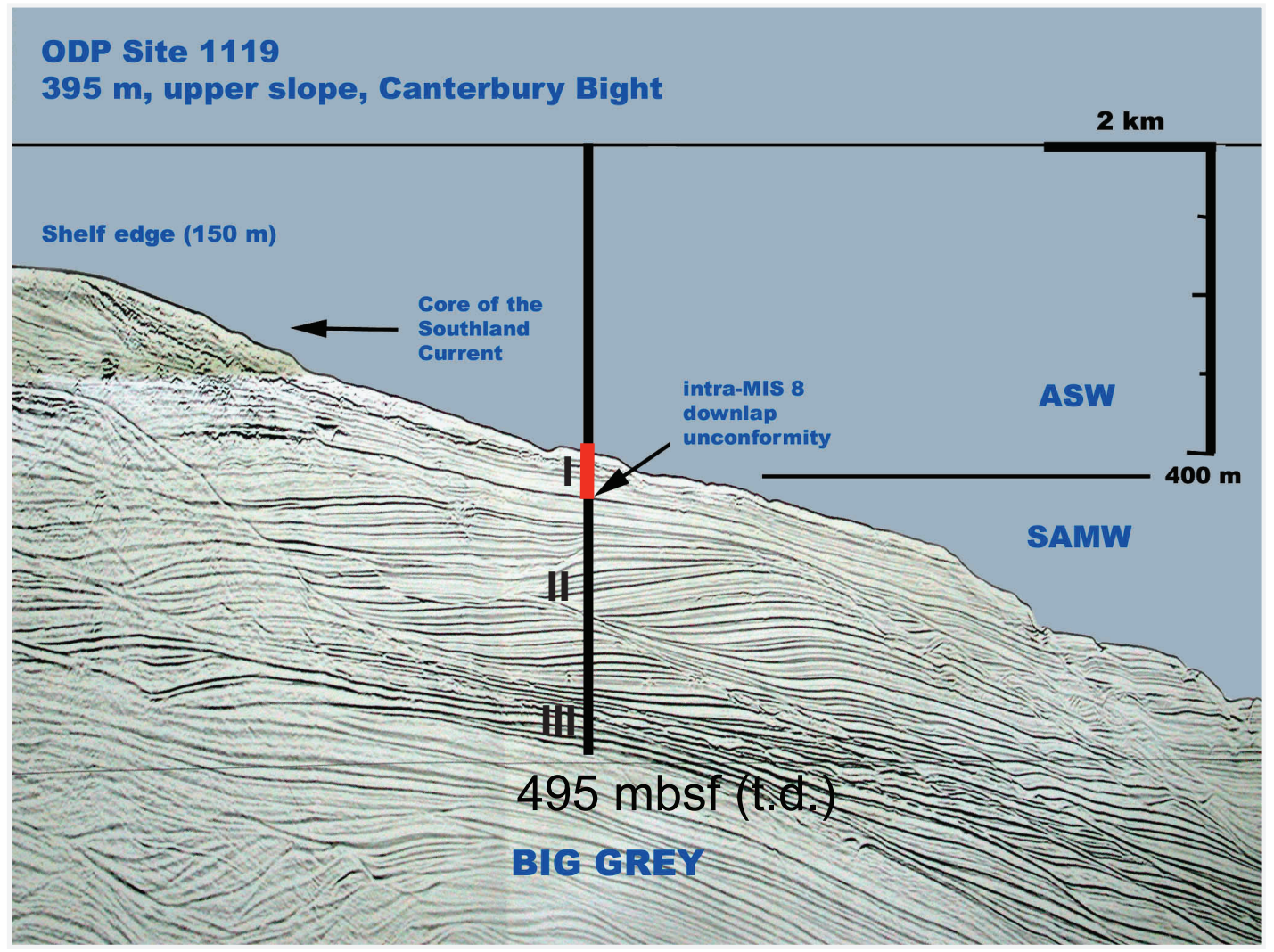



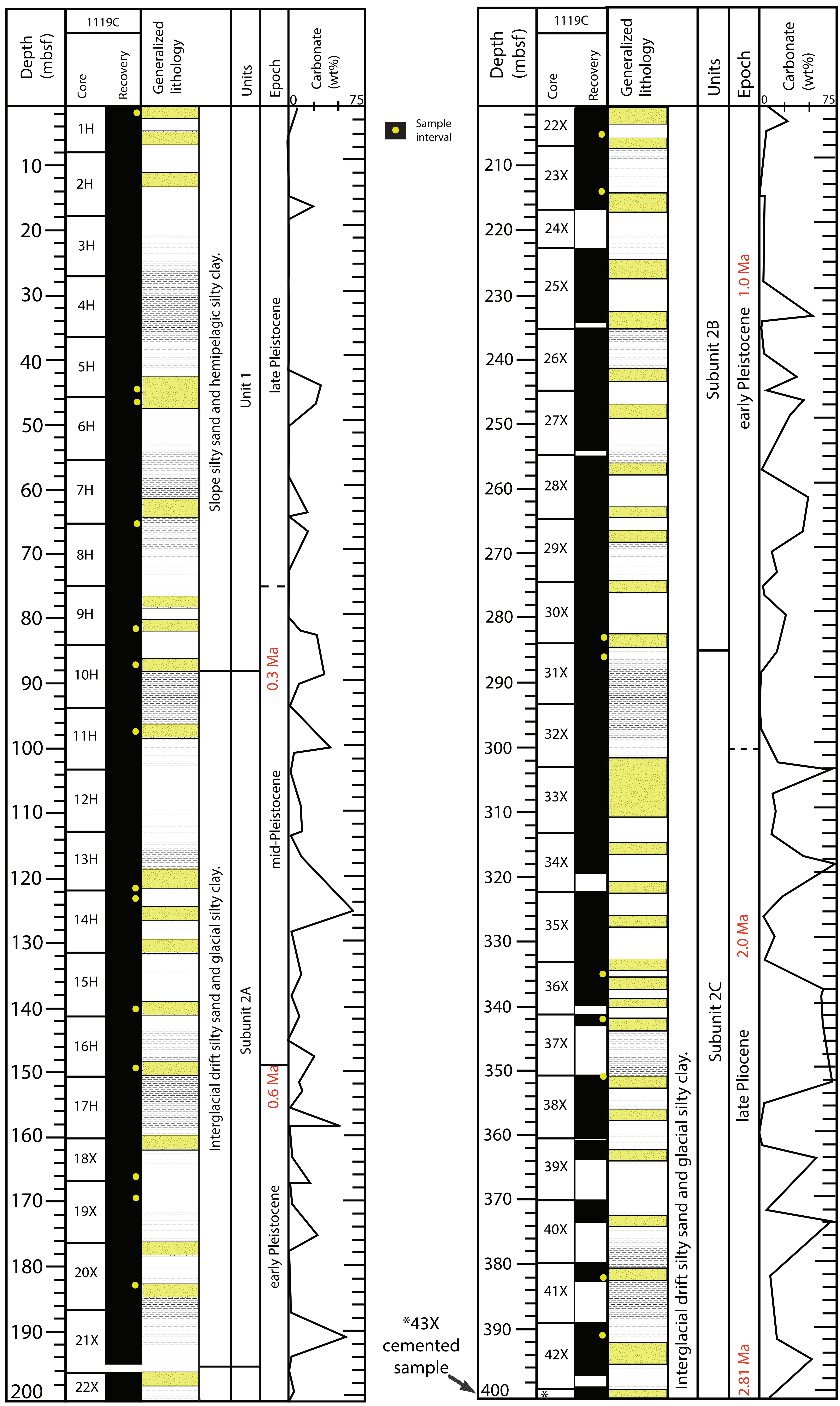
Figure 4
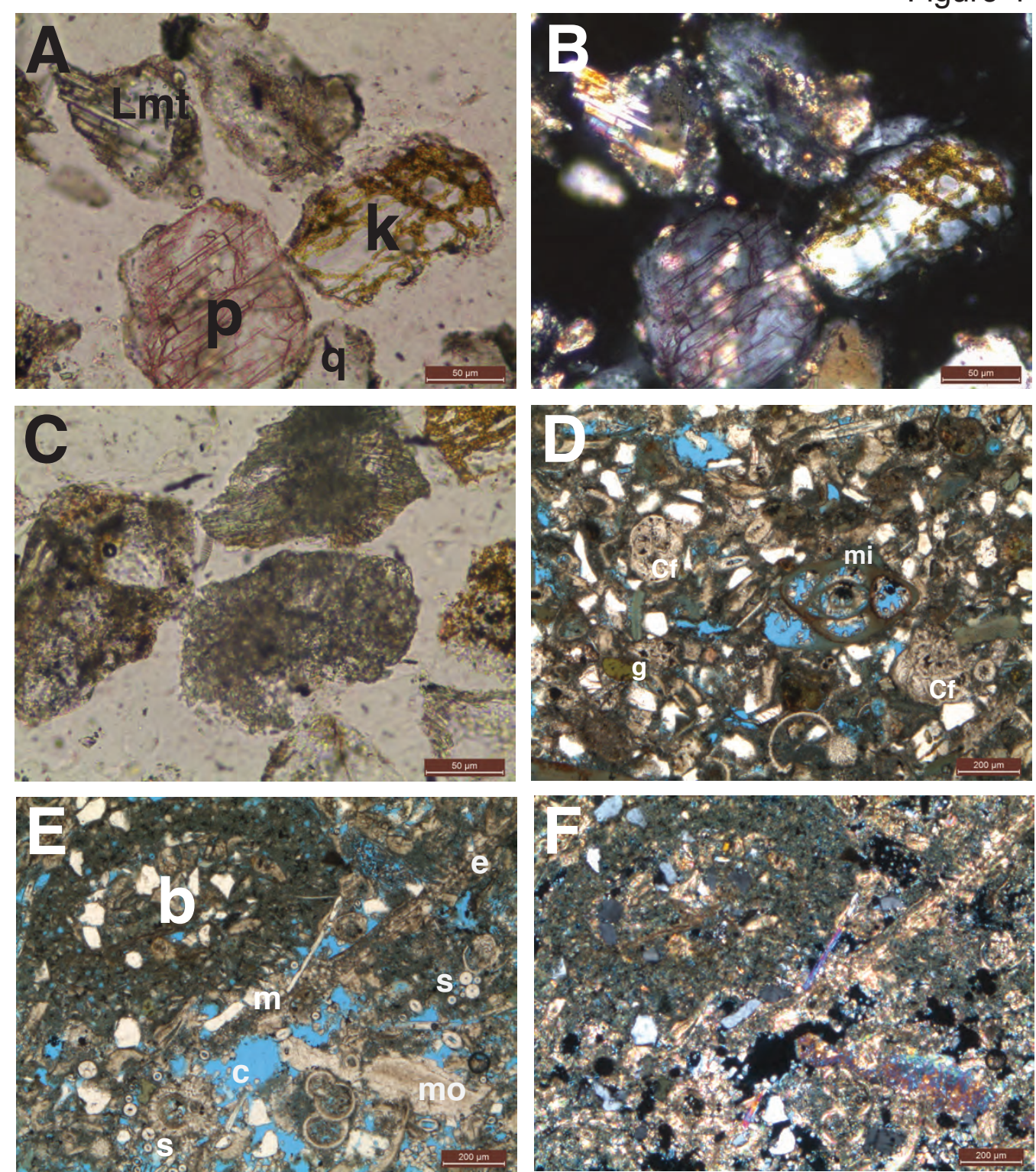
Figure 5

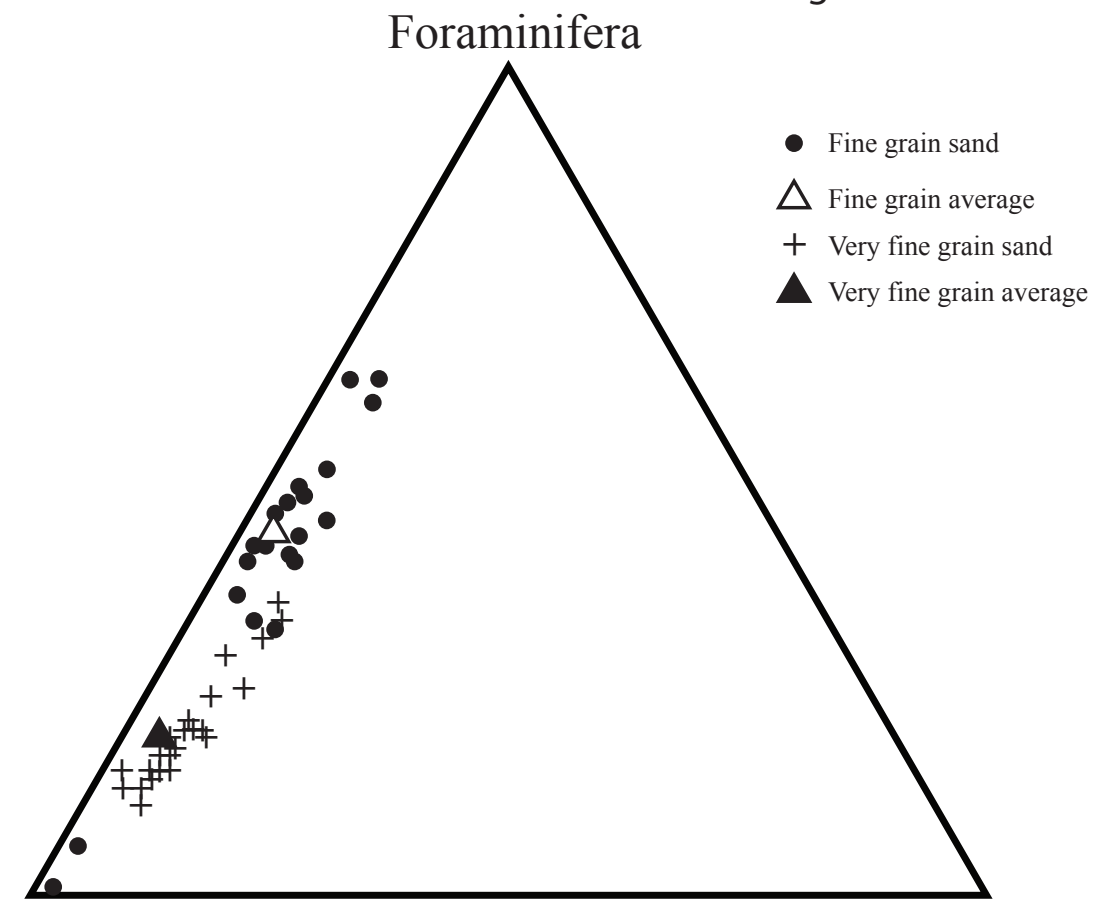

Terrigenous

Other Bioclast 
Figure 6

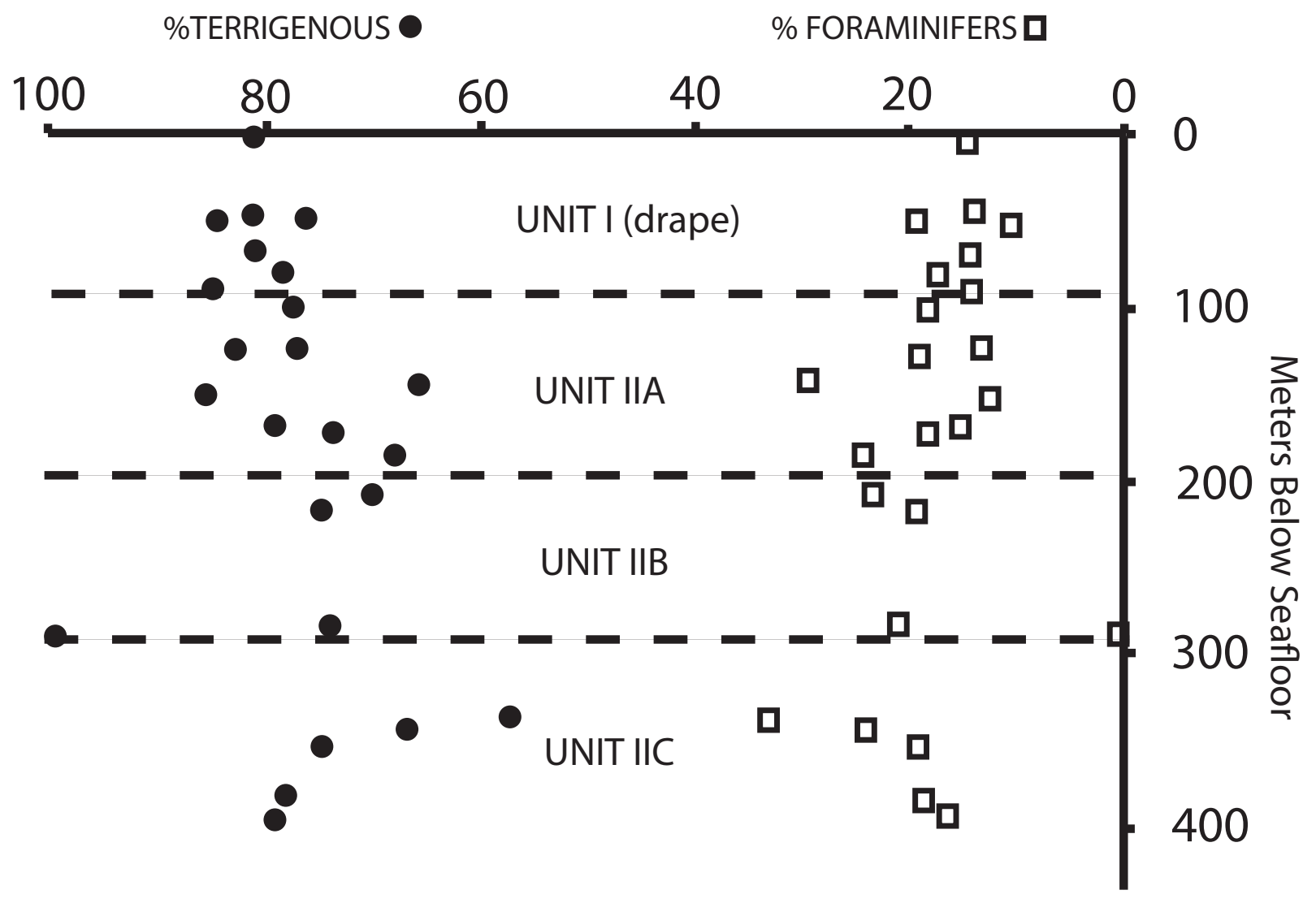


Figure 7

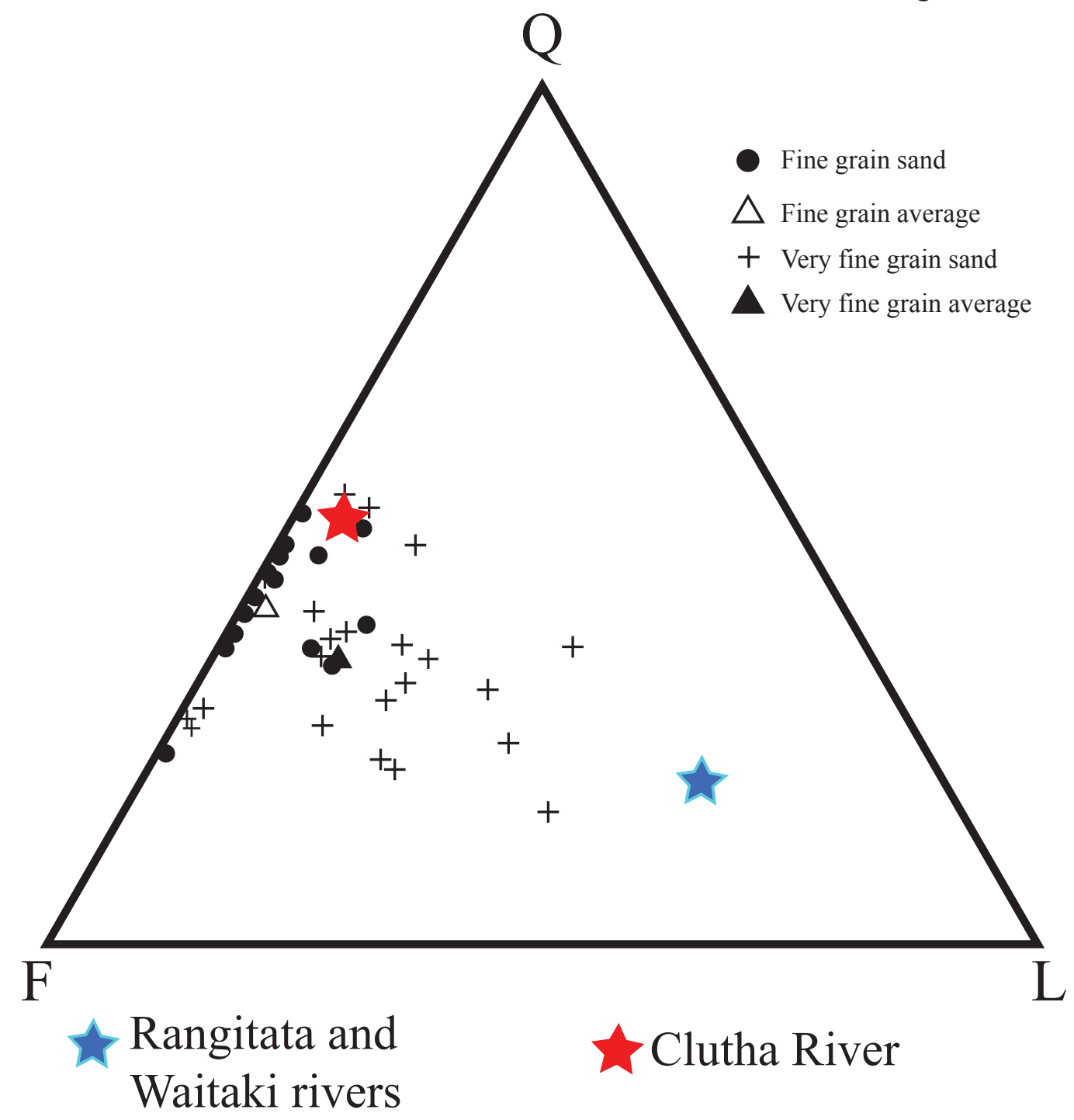




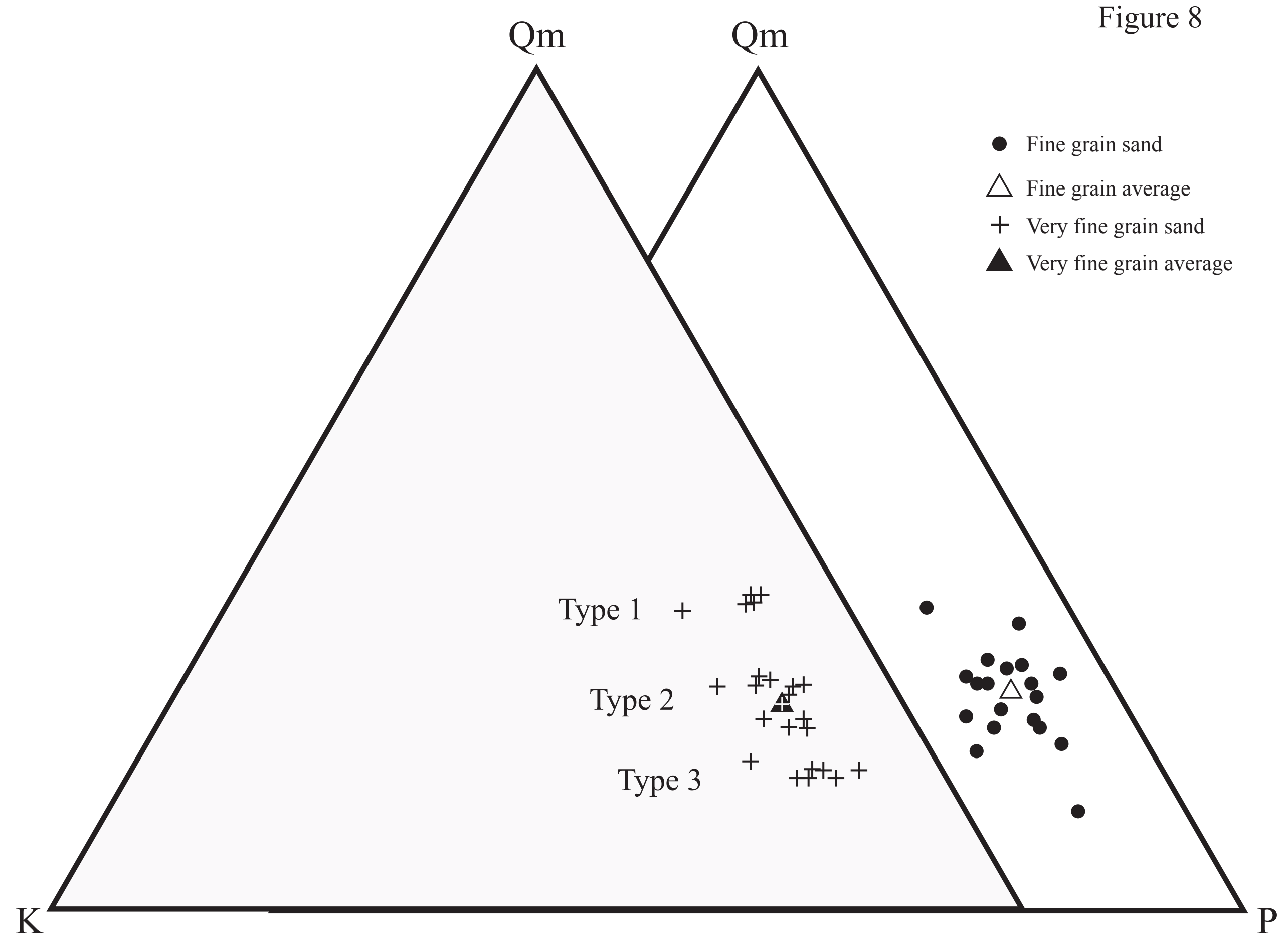




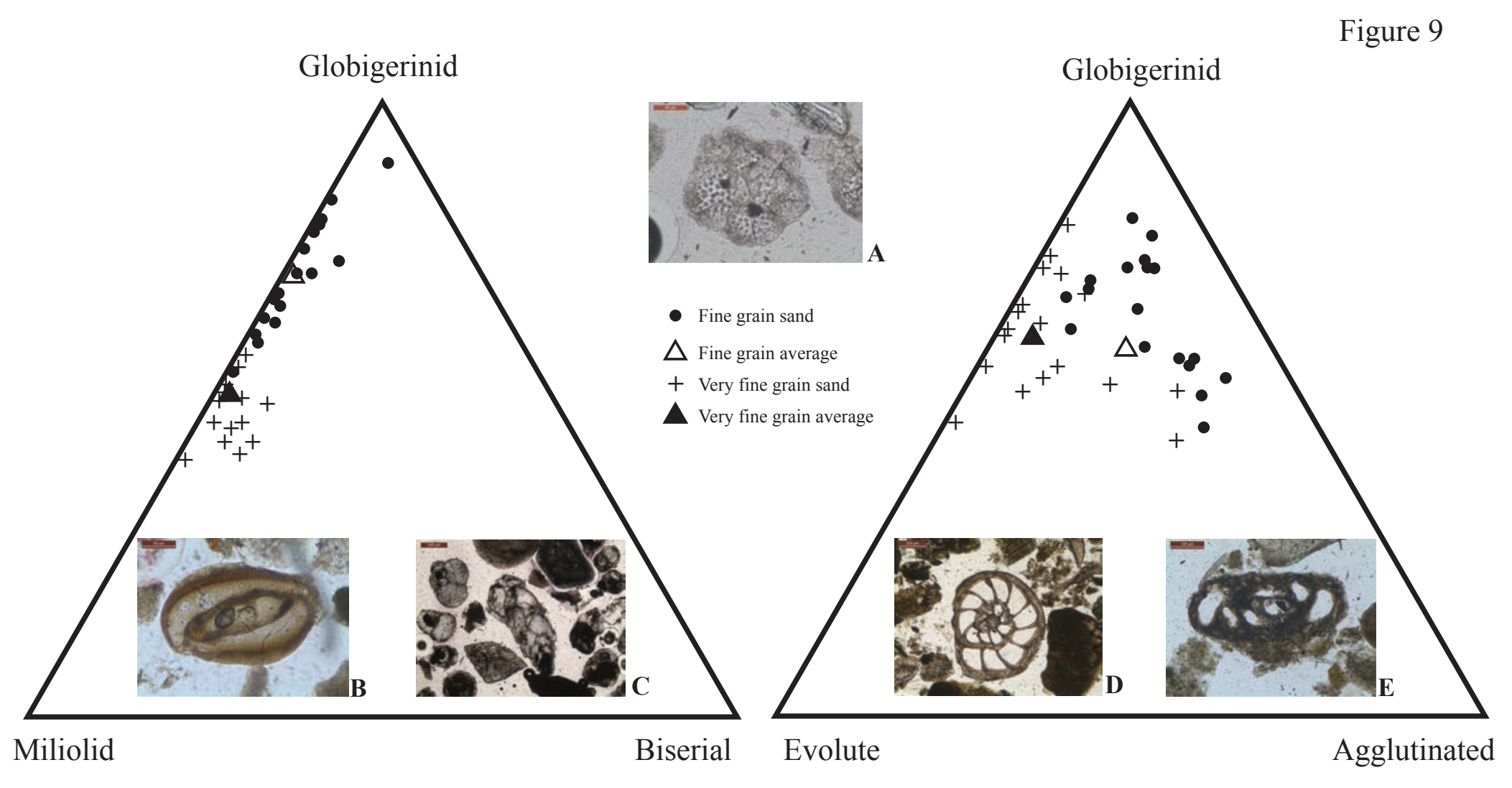


Figure 10

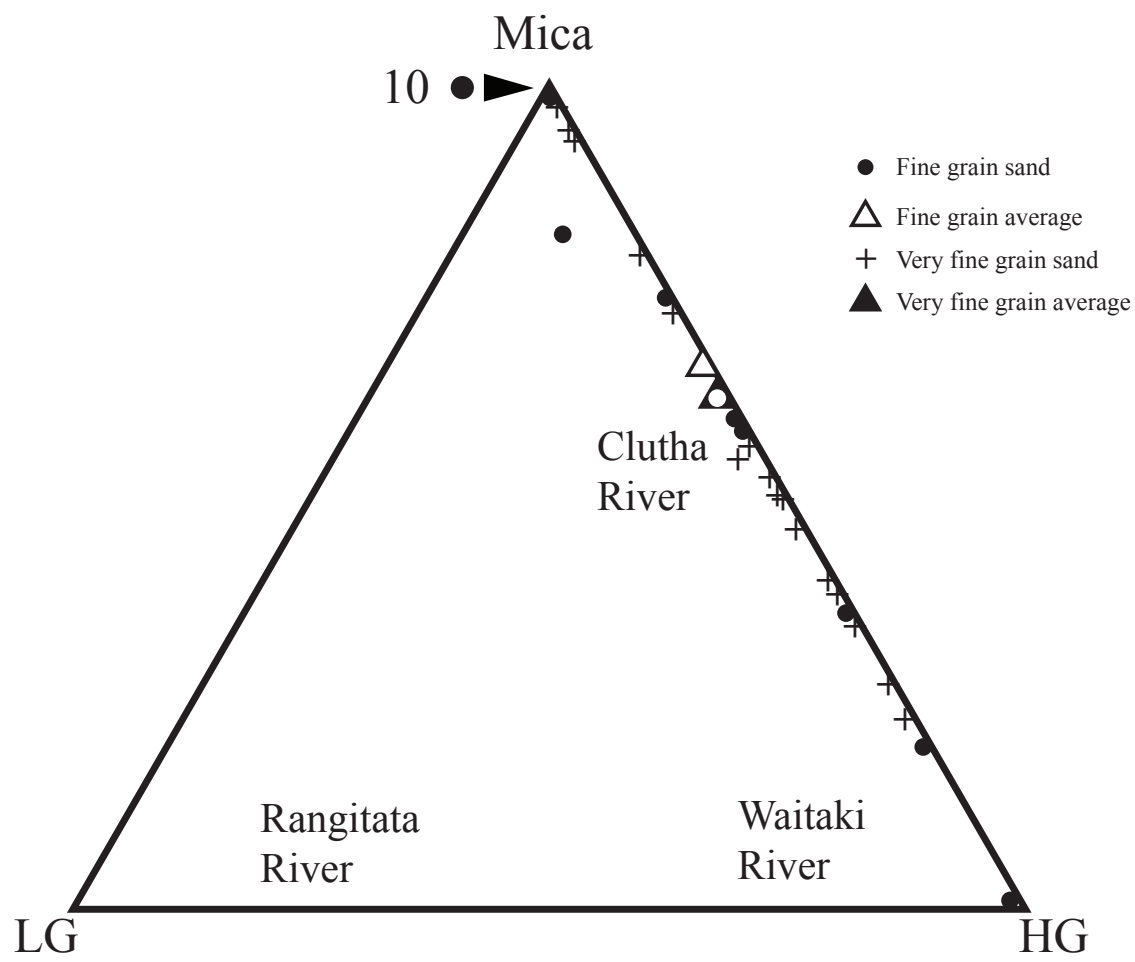


Table 1. Counted and Recalculated Parameters

Counted Parameters:

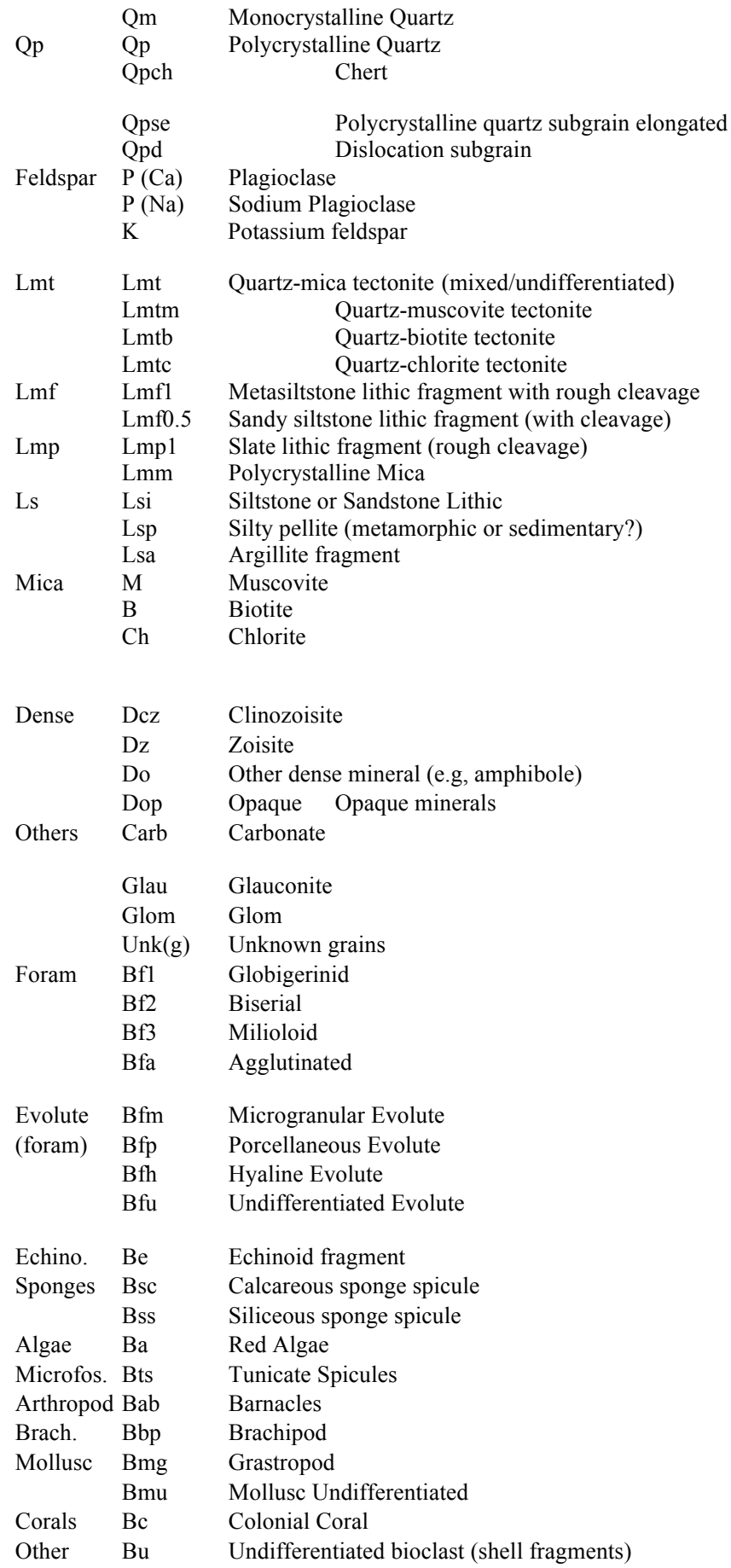

Recalculated Parameters:

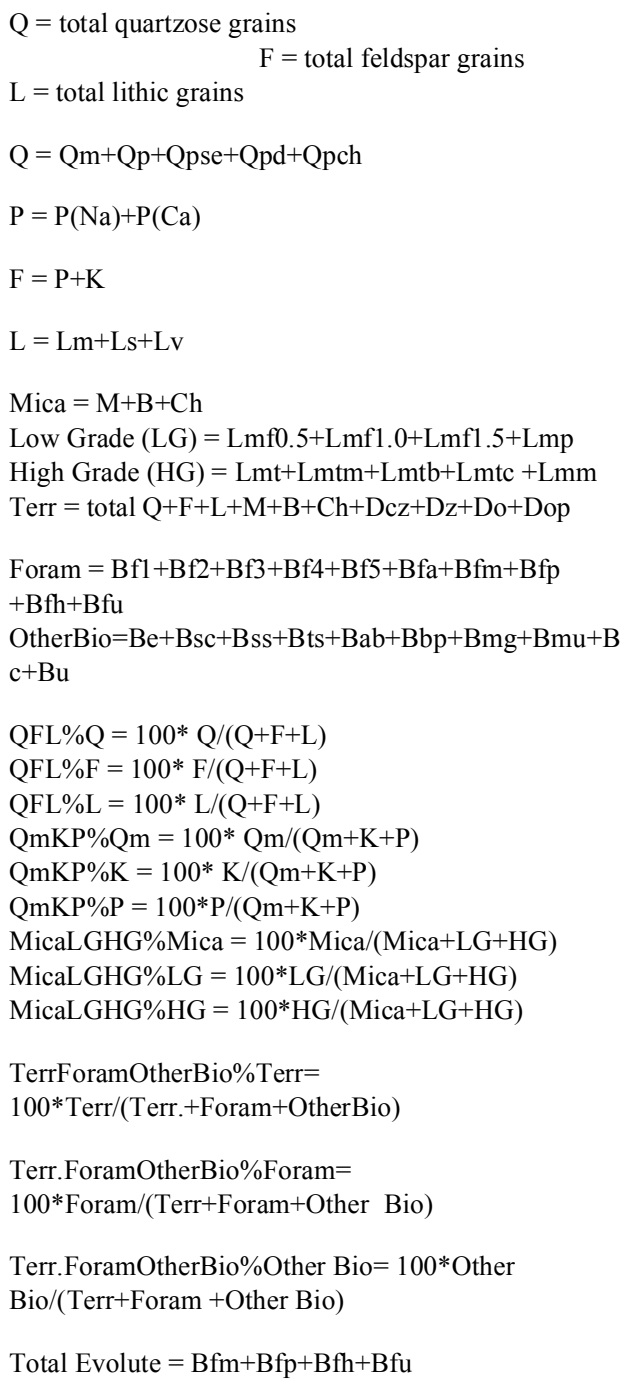

ForamPlotB $\%$ Globegerinid $=100 * \mathrm{Bfl} /(\mathrm{Bf} 1+\mathrm{Bfa}+$ total evolute)

ForamPlotB $\%$ Evolute $=100 *$ total evolute $/$ $(\mathrm{Bf} 1+\mathrm{Bfa}+$ total evolute)

ForamPlotB $\%$ Agglutinated $=100 * \mathrm{Bf} 1 /(\mathrm{Bf} 1+\mathrm{Bfa}+$ total evolute) 


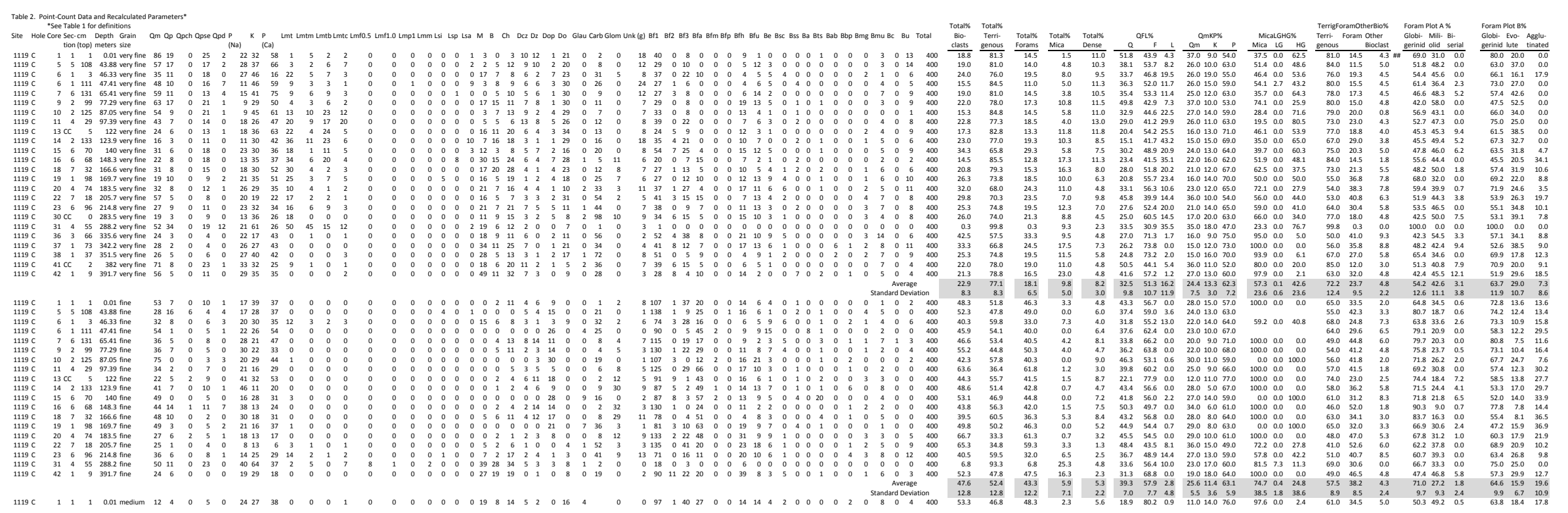

